\title{
LABOR MARKET DISCRIMINATION - ARE WOMEN STILL MORE SECONDARY WORKERS?
}

\author{
Jerzy REMBEZA (1), Kamila RADLIŃSKA (i)* \\ Faculty of Economics Sciences, Koszalin University of Technology, Koszalin, Poland
}

Received 19 March 2020; accepted 19 August 2020

\begin{abstract}
Discrimination based on gender is commonly observed on labor markets, although its scale and symptoms are different with regard to country and are subject to changes over time. Gender-related diverse flows on the labor market constitute one of its symptoms. The paper's main objective was to answer the question whether women on the labor market were still secondary workers. The analysis was conducted based on general models of flows on the labour market, examining connections between changes in a number of unemployed and changes in a number of employed men and women. There were applied data for eight OECD countries from various regions of the world. The obtained results were highly diversified depending on the analysis period and country. However, they confirmed that in the past women had been more secondary workers despite no differences in the unemployment rate. Gender impact was noticeable especially in the employment decrease periods. For data after the year 1990, gender-related differences disappeared or significantly decreased in four countries (Australia, Denmark, United Kingdom, United States), but in two of them (Canada, South Korea) - differences increased.
\end{abstract}

Keywords: labor market, employment, worker flows, gender, OECD countries, global crises.

JEL Classification: J16, J21, J71.

\section{Introduction}

Labor market is multi-dimensional, dynamic and internally diverse. It is characterized with considerable diversity in time and space, as well as with segmentation depending on education, occupation, gender, and age. This diversification is reflected e.g. in a different situation of men and women on the labor market - the phenomenon commonly observed regardless of the region and level of economic development. Reasons for these differences, their size and nature are different in different countries and they change over time. Usually, the situation of women on the labor market is worse, which is reflected in the lower level of professional activity, disproportionate participation in partial employment, dominance of employment in low-paid jobs, wage discrimination (Azmat et al., 2006; Bertrand \& Hallock,

*Corresponding author. E-mail: kamila.radlinska@tu.koszalin.pl

Copyright (c) 2020 The Author(s). Published by Vilnius Gediminas Technical University

This is an Open Access article distributed under the terms of the Creative Commons Attribution License (http://creativecommons. org/licenses/by/4.0/), which permits unrestricted use, distribution, and reproduction in any medium, provided the original author and source are credited. 
2001; Gimenez-Nadal \& Molina, 2014; Ridgeway, 1997). Social and family roles in some countries make women withdraw completely from professional activity (Kim et al., 2018), while in other states they make women accept lower remuneration, work part-time or work below their qualifications (Powell, 1997; Heywood et al., 2007). Women on the labor market are also marked by their low mobility, while their transfer from low-paid to high-paid jobs is less likely than in the case of men (Borland \& Coelli, 2016; Mosthaf et al., 2014; Jung \& Cho, 2020).

In the past decades, professional activity of women has significantly increased and now in many countries women constitute a half of all professionally active people. The female unemployment rate in many countries does not differ from the male unemployment rate. As a result, their situation on the labor market is improving. In some studies, it is even stated that gender is no longer significant for segmentation on the labor market, although the phenomenon of segmentation itself has not disappeared (Hudson, 2007; Albanesi \& Sahin, 2018; Bentolila et al., 2019). Many analyses show that despite the improved situation of women on the labor market, gender is still important for diversification of the labor market situation (Mukhopadhyay, 2016; Fortin, 2005, Ridgeway, 1997; Lažetić, 2020).

This paper refers to the duality labor market theory (Boston, 1990; Saint-Paul, 1996; Hudson, 2007; Graham \& Shakow, 1990). This theory assumes the population division into two groups: primary and secondary workers. This division may be conditioned by factors related to labor productivity, but it may also result from discrimination on the labor market. Empirical analyses show that women are more secondary workers than men (Fortin, 2005; Boston, 1990; Pascall, 2008). As a result, there should be expected gender-related diverse flows on the labor market. Guided by these reasons, the paper formulates three basic research objectives connected with answering the following questions:

- question 1: are there differences in net flows between men and women on the labor market in the countries under examination? Following the assumptions of the duality labor market theory, primary workers should flow between working persons and the unemployed, while secondary workers between working and inactive persons. Therefore, testing the hypothesis that women are more secondary workers than men would come down to the determination whether changes in a number of unemployed women respond more weakly to changes in a number of working women.

- question 2: whether there occurred any changes in net flows of men and women on the labor market during the analyzed period? Testing the hypothesis that differences between men and women have decreased or even disappeared would be related to the determination whether differences in connections between changes in a number of unemployed and working persons have decreased.

- question 3: does the phase of the economic cycle differentiate flows on the labor market and is this impact different in reference to men and women? If women are more secondary workers, then particularly in the recession periods significant differences in their flows on the labor market should be expected.

Regardless of those main objectives, the paper authors attempted to determine whether there were any differences in connections between changes in a number of unemployed and working persons among labor markets under examination, and if yes - how large. The 
analysis covers labor markets of eight OECD countries: Australia, Canada, Denmark, France, Japan, South Korea, United Kingdom (UK), and United States (US). All countries belong to a group of highly developed economies, however their labor markets show a high degree of diversity. It is manifested e.g. through a great diversity of the level and variability of the unemployment rate.

This paper is composed of three basic parts. The first one includes the review of literature concerning segmentation on the labor market and conditions for a distinct situation of women. The second part presents the analysis method and describes the applied data. The third part presents results of empirical studies. They are summarized in the last part of the paper, while attempting to answer questions related to its main objectives.

\section{Literature review}

Labor market is one of basic markets in every economy, hence the very large number of papers dedicated to its functioning. From the point of view of the labor area and objectives, studies concerning modeling of flows on the labor market and its segmentation, including those related to the gender significance, are primarily important. Models of flows on the labor market treat this market as a dynamic system, within which continuous flows occur among three basic groups of people: working, unemployed and inactive. Every mentioned group is characterized with internal diversification related e.g. to gender, age, education. On the diversity of individuals, there is imposed the diversification of enterprises that have their own preferences in the area of employment of workers, diversity of institutional considerations, including regulations of the labor market, customs and standards, differentiation of behaviors within the economic cycle. Based on such a division, there was specified the probability of transfer between particular groups and factors affecting those flows (Bachmann \& Sinning, 2016; Blanchard et al., 1990; Elsby et al., 2009; Petrongolo \& Pissarides, 2001; Shimer, 2012). Blanchard et al. (1990), based on data for the US labor market, stated that the value of inflows to employment from the unemployed and inactive persons was similar and significantly reflexive, which indicated similarities between the unemployment and inactivity states. However, they also found significant differences. In the recession period, flows between the working and unemployed persons in both directions were increasing, while flows between the working and inactive persons were decreasing. A decrease in employment in the recession period resulted more from high rates of job destruction than from the low rate of their creation. Similarly, according to Elsby et al. (2009), understanding of cyclical fluctuations in unemployment requires both the explanation of anti-cyclical unemployment inflows and procyclical outflows. In turn, Shimer (2012) stated that the probability of finding a job explained fluctuations in the unemployment rate in the US to a greater extent than the probability of losing a job, while fluctuations in the probability of leaving employment did not really matter. Differences in the socio-economic and demographic composition of the working and unemployed persons, so-called composition effect, were insignificant for unemployment outflows. Bachmann and Sinning (2016) attested the significance of the composition effects, while differences between groups related to education were the most important and those connected with gender and age were less important. In the light of research of Amable et al. 
(2006), education was important for inactivity, while it was insignificant for unemployment. The Jung and Cho (2020) analysis leads to similar conclusions.

Standard models of dynamic balance on the labor market referring to the neoclassical model assumptions usually ignore barriers to mobility on the labor market. In the view of critics of such an approach, it leads to problems with explaining discrimination and monopolies on the labor market and to unemployment (Hall, 1972). The dual labor market theory (Dickens \& Lang, 1985; Ogawa, 2019; Wachter, 1972) is based on assumptions that are alternative, but not necessarily contrary to the neoclassical theory. This theory assumes that economy covers two different sectors: primary and secondary sector. The very division refers to empirical observations, but it is not based on the strict theory and has no strictly specified assumptions (Graham \& Shakow, 1990). The primary market includes generally jobs and employees with high wages, stable employment, good working conditions with benefits, unionization, low unemployment rate, as well as it is created by large monopolistic companies, prime age men, educated, while the secondary market includes jobs and employees with low wages, unstable employment, poor working conditions without benefits, no unionization, high unemployment rate, as well as it is created by small companies from the competitive market, with disadvantaged groups (minorities, women, youth, seniors, not educated). Usually it is assumed that secondary employees more often resign from their job and less commit to its search when they are not employed. Companies dismiss them in the first instance, as they prefer primary workers while hiring. The model assumes segmentation on the labor market, while its reasons and probability and scale of migrations between both groups constitute a separate issue. Empirical analyses may adopt simplifying assumptions, e.g. that in the case of losing their job primary workers transfer entirely to the unemployed, while secondary workers - to inactive persons (Blanchard et al., 1990). Primary workers are employed for fixed wages, while their employment is determined by the demand on the property market. Secondary workers are employed on the competitive market and their market is always in balance (Ogawa, 2019).

Segmentation is a well-documented in empirical studies phenomenon occurring on the labor market (Blanchard et al., 1990; Dickens \& Lang, 1985; Eichhorst et al., 2017; McDonald \& Solow, 1985; Ogawa, 2019; Osterman, 1985; Jung \& Cho, 2020; Pascall, 2008). Although changes in factors generating segmentation are observed, the very phenomenon does not disappear. The 2008 financial crisis has resulted even in an increased segmentation (Eichhorst et al., 2017; Sánchez-Mira, 2019). The empirical studies' results show that when secondary workers lose their job, they transfer mainly to inactive persons, while primary workers - to the unemployed. In the economic cycle, primary workers are characterized with a larger variability of employment. In the recession period, wage-related disparities between primary and secondary workers increase. On the majority of markets it is confirmed that division into two employee groups largely corresponds with the population division by its gender, age, education, nationality. The Hudson's (2007) analysis for the US market indicates, though, reduced significance of the criteria based on gender and age, with an increased significance of unionization and nationality (immigrants constitute mainly secondary workers).

The phenomenon of duality on the labor market may be differently assessed depending on the time horizon and conditions of the analysis. On the one hand, they conduce to em- 
ployment of workers for longer and shorter periods, thus increasing companies' effectiveness and stabilizing economy (Saint-Paul, 1996). However, these stabilizing effects may concern only a short period, not necessarily the medium one. Duality may overcome barriers resulting from price hardening in economy, but does not automatically ensure overcoming the barrier of effective demand on the property market (Ogawa, 2019). From the point of view of economic results, but also economic policy, it is also important whether segmentation results from the factors related to labor productivity (e.g. education, experience, commitment), or whether it is discriminating, not related to productivity, and whether the labor market ensures mobility (transfer from secondary to primary). Outputs of many analyses show that differences in the wage level between primary and secondary workers partially result from the factors not related to productivity (Boston, 1990; Jung \& Cho, 2020). There are also barriers to mobility between these two groups of employees (Boston, 1990; Hudson, 2007). Mobility on the labor market, tendency to stay unemployed or inactive for a longer period depend on the current economic situation, regulations of the labor market, level of education.

In the past decades, the significance of women on the labor market has decidedly increased, as now women constitute almost a half of professionally active population in many countries. Segmentation on the labor market results from the productivity-related factors that are not discriminatory, but also from the factors that are unambiguously discriminative. It means that gender is significant for diversification of a situation on the labor market. Therefore, this diversification results from a separate box of preferences determining decisions on labor supply (Agarwal, 1997). Many studies emphasize the significance of child care as a factor differentiating the male and female situation on the labor market. Therefore, the labor supply model considers also the quality of children upbringing, apart from the usefulness of consumption and free time (Powell, 1997; Sánchez-Mira, 2019). The household features, i.e. number of small children, revenue from outside one's job, have a significant impact on professional inactivity of women or their part-time work. Moreover, child care inclines women to accept lower salaries in exchange for family-friendly conveniences offered by employers (Heywood et al., 2007). Introduction of regulations concerning such solutions as parental leave and launch of governmental programs oriented towards the promotion of women equality in professional life have only marginally improved the female situation on the labor market (Mukhopadhyay, 2016; Pascall, 2008). Analyses conducted for various countries usually indicate that the probability of getting a low-paid job is higher for women than for men. Moreover, women are also less likely to transfer from low-paid to high-paid jobs (Borland \& Coelli, 2016; Mosthaf et al., 2014). Although employers hire women more and more eagerly, following their level of education and discipline, women are still only marginally taking up jobs so far assigned to men (Fortin, 2005; Ridgeway, 1997). Segmentation on the labor market, at least partially discriminatory, manifests itself in the wage gap (Jung \& Cho, 2020; Acemoglu \& Autor, 2011; Fernández-Macías \& Vacas, 2015; Seguino, 2000). The Australian example shows that the labor market reforms reducing women discrimination have not affected the differences in male and female wage levels (Borland \& Coelli, 2016). Research of Jung and Cho (2020) for the labor market in South Korea indicates gender as a basic factor differentiating wages. 
Apart from their internal diversity, labor markets are also marked by their significant spatial diversification. It manifests itself through the unemployment participation rate, unemployment sensitivity to economic changes, mobility of working persons. These differences result from the conditions of functioning of the labor market, product market and financial markets, macroeconomic politics, regulations of labor markets (Blanchard, 2006; Nickell et al., 2004; Siebert, 1997). In many countries, there are applied instruments encouraging to quickly enter employment and shorten an unemployment period, e.g. sanctions for rejecting wage offers or subsidy in the case of accepting low-paid job offers (Pascall, 2008; Stephan, 2010; Svarer, 2011; Van den Berg \& Vikström, 2014). Controversiality of these instruments results from the fact that women have an over-proportional participation in low-paid jobs (Mosthaf et al., 2014). Its consequence may be the consolidated existing differentiation among groups of working persons (Cappellari, 2007; Buddelmeyer et al., 2010).

\section{Analysis method and data}

The research concept and objective are based on general models of flows on the labor market and on their conditions resulting from the market segmentation by gender, i.e. gender designation in fluctuations on the labor market. A general model of flows between working persons $(E)$, unemployed $(U)$, and inactive persons $(N)$, in which changes within particular groups in the period $t$ are described as follows (Petrongolo \& Pissarides, 2001; Shimer, 2012):

$$
\begin{aligned}
& \Delta E_{t}=\theta_{t}^{U E} U_{t}+\theta_{t}^{N E} N_{t}-\left(\theta_{t}^{E U}+\theta_{t}^{E N}\right) E_{t} ; \\
& \Delta U_{t}=\theta_{t}^{E U} E_{t}+\theta_{t}^{N U} N_{t}-\left(\theta_{t}^{U E}+\theta_{t}^{U N}\right) U_{t} ; \\
& \Delta N_{t}=\theta_{t}^{E N} E_{t}+\theta_{t}^{U N} U_{t}-\left(\theta_{t}^{N E}+\theta_{t}^{N U}\right) N_{t},
\end{aligned}
$$

where $\theta^{X Y}$ are rates of flow between the stock $\mathrm{X}$ and the stock $\mathrm{Y}$. The model may be presented in the form of net flows between particular groups.

According to it, changes in a number of the unemployed result from net flows between working and unemployed persons and between unemployed and inactive persons:

$$
\Delta U_{t}=\left(\theta_{t}^{E U} E_{t}-\theta_{t}^{U E} U_{t}\right)+\left(\theta_{t}^{N U} N_{t}-\theta_{t}^{U N} U_{t}\right)
$$

or in a simplified form

$$
\Delta U_{t}=\beta_{1} \Delta E_{t}+\beta_{2} \Delta N_{t}
$$

where the first part determines net inflows to the unemployed from the employed and the second part - net inflows from inactive persons.

According to the above identity, changes in a number of the unemployed result from net inflows from the employed or from inactivity. If a decrease in a number of working persons is larger than an increase in a number of unemployed, it means that, considering net results of flows, a part of working persons transferred to an unemployed group, while the other part - to a group of inactive persons. If a decrease in a number of working persons is equal 
to an increase in a number of unemployed, it means that net flows occur only between these groups and are equivalent.

A simple regression model was applied to empirically verify that connection:

$$
\Delta U_{t}=\beta \Delta E_{t}+\varepsilon_{t},
$$

where the $\beta$ coefficient describes to what extent net flows go between working and unemployed persons and to what extent between remaining groups. Adopting a negative connection between changes in a number of the unemployed and changes in a number of working persons, it should be expected that it should be within the range $(0,-1)$. The closer the $\beta$ coefficient to -1 , the more equivalent the nature of flows between working and unemployed persons. The closer the $\beta$ coefficient to 0 , the higher the participation of flows between working and inactive persons in changes on the labor market.

Adopting an assumption that men, representing primary workers, usually switch to the unemployed when they lose their job, while women - secondary workers - to inactive persons. The $\beta$ coefficients closer to 0 for a group of women would indicate that women show more features of secondary workers. Two types of variables were applied in the regression models used in the empirical study. In the first version, variables included the first disparities in a number of working and unemployed persons, while in the second version - variables included cyclical components of a number of unemployed and working persons ${ }^{1}$. Cyclical components were selected with use of the Hodrick-Prescott filter.

While testing flows in particular periods of the economic cycle, there was applied the model where an endogenous variable was constituted by cyclical components of a number of the unemployed and exogenous variables were positive and negative cyclical components of a number of working persons:

$$
U_{c, t}=\beta_{1} E_{c, t}^{+}+\beta_{1} E_{c, t}^{-}+\varepsilon_{t} .
$$

In the analysis, the models of flows on the labour market described with the Eqs (4) and (5) were applied. Simplicity and not too high requirements concerning data are advantages of the methodology applied in the paper. It is based on data referring to a number of working and unemployed persons, which are relatively easily accessible, enabling to compare national markets and recording changes over time. The models (4) and (5) are based on data having the nature of stocks, instead of flows, as the starting model (1). A limitation of such an approach is constituted by the possibility of analyzing only the results of net flows, instead of direct flows among working, unemployed and inactive persons. Moreover, in the study aggregate values of working persons were observed, without distinguishing between persons working full- and part-time.

Classic regression coefficients in the models (4) and (5) allow for the determination of a general response of changes in a number of unemployed to a change in a number of employed men and women. The model assessments' stability was evaluated with use of its recursive modification, i.e. rolling regression with a movable window in the size of 20 periods. Recursive/rolling modification of the regression coefficient extends interpretative possibilities

\footnotetext{
${ }^{1}$ Results of the ADF tests showed that numbers of working and unemployed persons constituted non-stationary variables, while their first differences and cyclical components were stationary.
} 
of the correlation analysis by the indication of variable convergence paths. It was applied to conclude whether the analysed dependence was stable over time and whether its force was subject to changes.

The conducted analyses were based on the aggregated yearly data on a number of employed and unemployed men and women aged over 15. The International Labour Organization base constituted the data source. The spatial scope of the research covered labour markets of eight OECD members: Australia, Canada, Denmark, France, Japan, South Korea, Great Britain, and United States. The adopted research time depended on the availability of data. In the case of EU states, i.e. Denmark, France, Great Britain, there were applied data for the years 1983-2017, while in the case of the remaining countries - for longer periods (USA 1948-2018, Japan 1953-2018, Korea 1970-2017, Canada 1976-2018, Australia 1979-2017). There was adopted an assumption that the comparison of labour markets in particular countries considered data since 1981, while the analysis of changes over time applied the broader available scope of data. That procedure resulted, on the one hand, from the comparability and extension of interpretative possibilities of research results and, on the other hand, from order reasons.

\section{Research results and discussion}

In this paper, analyses concern labor markets in eight countries from different regions of the world, which belong to the OECD. This selection results in a relatively low diversity of the level of economic development of the countries under examination. Data concerning basic values describing labor markets, including participation and unemployment rates, indicate, on the one hand, some similarities, but also the specificity of national labor markets (see Appendix Figure 3). Mainly the unemployment rate was characterized by a great average diversity (Table 1). In Japan and South Korea, an average unemployment rate did not exceed 4\%, in Canada it exceeded 8\%, while in France - 9\%. Apart from spatial differentiation, the unemployment rate

Table 1. Basic statistics of a number of working persons and the unemployment rate in selected countries in the years 1981-2018 (source: own calculations based on the ILO data)

\begin{tabular}{|l|c|c|c|c|c|c|}
\hline \multirow{2}{*}{ Country } & \multicolumn{2}{|c|}{$\begin{array}{c}\text { Annual growth rate for a number of } \\
\text { working persons (\%) }\end{array}$} & \multicolumn{3}{c|}{ Unemployment rate (\%) } \\
\cline { 2 - 7 } & Total & Male & Female & Total & Male & Female \\
\hline Australia & 1.80 & 1.32 & 2.48 & 6.94 & 6.87 & 7.06 \\
\hline Canada & 1.39 & 1.01 & 1.88 & 8.28 & 8.57 & 7.94 \\
\hline Denmark & 0.46 & 0.35 & 0.59 & 6.50 & 5.98 & 7.11 \\
\hline France & 0.68 & 0.28 & 1.17 & 9.83 & 8.73 & 11.21 \\
\hline Japan & 0.49 & 0.24 & 0.84 & 3.51 & 3.59 & 3.38 \\
\hline Rep. of Korea & 1.79 & 1.59 & 2.09 & 3.50 & 3.98 & 2.79 \\
\hline UK & 0.93 & 0.61 & 1.34 & 7.40 & 8.06 & 6.56 \\
\hline US & 1.18 & 0.97 & 1.45 & 6.25 & 6.37 & 6.10 \\
\hline
\end{tabular}

Note: ${ }^{*} 1983-2018$. 
is characterized with considerable changes over time, while its gendered nature is relatively insignificant. Differences in the unemployment rate for men and women were usually slight. Unemployment of women was averagely higher mainly in France, while in United Kingdom the unemployment rate was higher for men. However, also in those countries after the year 2000 differences between the unemployment rate for men and women decreased.

In all countries under examination, employment demonstrated a long-term upward trend, regardless of gender. In countries with a higher increase in male employment, the female employment rate was higher as well (Australia, Canada, South Korea). However, the female employment growth rate was significantly higher when it was caused by an increase in the participation rate, apart from an increase in the population rate. Although the male participation rate was higher in the entire analyzed period, differences between genders were significantly reduced. It resulted mainly from an increase in the female participation rate, but also (apart from Japan and Korea) from a small decrease in the male participation rate. Alignment of participation rates was noticeable particularly in Australia, Canada and France, while Denmark was a special case, as differences between genders were subtle throughout the entire analyzed period. Relatively large differences were maintained in Japan and Korea (see Appendix Figure 4).

General descriptions of the labor market show that although there occurred differences between particular countries as to the unemployment and female participation rates, simultaneously in all countries the alignment of participation rates occurred, while differences in the unemployment rate for men and women were slight. Following these assumptions, one may suppose that differences concerning employment and unemployment of men and women have largely - if not completely - disappeared. Analyses conducted in the paper confirm such opinions only partially.

Table 2 presents the results concerning the connection between changes in a number of unemployed and changes in a number of working persons obtained based on the model (4). Those results were similar for both model variants, differing only with a type of introduced variables (first differences or deviations from the trend). As expected, interactions between changes in a number of unemployed and working persons were negative, but showed distinct disparities with regard to country and gender. The strongest negative connection characterized labor markets in the US, Canada, and France. In the US, together with an increase/ decrease in a number of working persons by 1 , a number of unemployed increased/decreased by 0.71 for the first differences and by 0.73 for deviations from the trend. In Canada, those values came, respectively, to 0.65 and 0.62 . According to the adopted interpretation of those coefficients, it meant that the majority of net flows on the labor market proceeded between the unemployed and working persons. In Australia, Denmark, Korea and UK, those coefficients were slightly lower, from 0.4 to 0.6 . Deviating results were obtained for the labor market in Japan. Links between changes in a number of unemployed and working persons were very weak in that country, in particular for the model with the first differences. These results indicate that the majority of flows on the labor market in this country proceed between working and inactive persons.

Comparison of results obtained separately for men and women enables to draw a general conclusion. In all countries the $\beta$ coefficients were lower for women. Therefore, male net 
Table 2. Changes in a number of unemployed and changes in a number of working persons - results of the regression analysis (model estimated based on the first differences in variables and model estimated based on deviations of variables from the trend) in selected countries in the years 1981-2018 (source: own calculations based on the ILO data)

\begin{tabular}{|c|c|c|c|c|c|c|}
\hline \multirow{2}{*}{ Country } & \multicolumn{3}{|c|}{ First differencies } & \multicolumn{3}{|c|}{ Deviation from trend } \\
\hline & Total & Male & Female & Total & Male & Female \\
\hline \multicolumn{7}{|c|}{ Australia } \\
\hline$-\beta$ & $\begin{array}{l}-0.5125 \\
(0.0631)\end{array}$ & $\begin{array}{l}-0.6574 \\
(0.0612)\end{array}$ & $\begin{array}{l}-0.2829 \\
(0.0585)\end{array}$ & $\begin{array}{l}-0.4702 \\
(0.0555)\end{array}$ & $\begin{array}{l}-0.6213 \\
(0.0607)\end{array}$ & $\begin{array}{l}-0.2634 \\
(0.0459)\end{array}$ \\
\hline$-\mathrm{R}^{2}$ & 0.65 & 0.77 & 0.40 & 0.66 & 0.74 & 0.47 \\
\hline \multicolumn{7}{|c|}{ Canada } \\
\hline$-\beta$ & $\begin{array}{l}-0.6467 \\
(0.0592)\end{array}$ & $\begin{array}{l}-0.7196 \\
(0.0464)\end{array}$ & $\begin{array}{l}-0.4160 \\
(0.0759)\end{array}$ & $\begin{array}{l}-0.6188 \\
(0.0570)\end{array}$ & $\begin{array}{l}-0.7192 \\
(0.0467)\end{array}$ & $\begin{array}{l}-0.4278 \\
(0.0644)\end{array}$ \\
\hline$-\mathrm{R}^{2}$ & 0.77 & 0.87 & 0.45 & 0.77 & 0.87 & 0.55 \\
\hline \multicolumn{7}{|c|}{ Denmark } \\
\hline$-\beta$ & $\begin{array}{l}-0.3763 \\
(0.0950)\end{array}$ & $\begin{array}{l}-0.4691 \\
(0.0876)\end{array}$ & $\begin{array}{l}-0.2258 \\
(0.0929)\end{array}$ & $\begin{array}{l}-0.4644 \\
(0.0815)\end{array}$ & $\begin{array}{l}-0.5427 \\
(0.0729)\end{array}$ & $\begin{array}{l}-0.3054 \\
(0.0818)\end{array}$ \\
\hline$-\mathrm{R}^{2}$ & 0.33 & 0.47 & 0.16 & 0.50 & 0.63 & 0.30 \\
\hline \multicolumn{7}{|c|}{ France } \\
\hline$-\beta$ & $\begin{array}{l}-0.6250 \\
(0.1010)\end{array}$ & $\begin{array}{l}-0.7561 \\
(0.0874)\end{array}$ & $\begin{array}{l}-0.3978 \\
(0.1025)\end{array}$ & $\begin{array}{l}-0.7349 \\
(0.0922)\end{array}$ & $\begin{array}{l}-0.7969 \\
(0.0664)\end{array}$ & $\begin{array}{l}-0.4996 \\
(0.1086)\end{array}$ \\
\hline$-\mathrm{R}^{2}$ & 0.54 & 0.70 & 0.32 & 0.66 & 0.81 & 0.39 \\
\hline \multicolumn{7}{|c|}{ Japan } \\
\hline$-\beta$ & $\begin{array}{c}-0.0322 \\
(0.0449) \\
\end{array}$ & $\begin{array}{l}-0.0240 \\
(0.0287)\end{array}$ & $\begin{array}{l}-0.0258 \\
(0.0366) \\
\end{array}$ & $\begin{array}{l}-0.1708 \\
(0.0466) \\
\end{array}$ & $\begin{array}{l}-0.2061 \\
(0.0524) \\
\end{array}$ & $\begin{array}{l}-0.1200 \\
0.0380)\end{array}$ \\
\hline$-\mathrm{R}^{2}$ & 0.01 & 0.02 & 0.01 & 0.28 & 0.30 & 0.22 \\
\hline \multicolumn{7}{|c|}{ R. of Korea } \\
\hline$-\beta$ & $\begin{array}{l}-0.4298 \\
(0.0496)\end{array}$ & $\begin{array}{l}-0.6118 \\
(0.0623)\end{array}$ & $\begin{array}{l}-0.2163 \\
(0.0374)\end{array}$ & $\begin{array}{l}-0.3961 \\
(0.0595)\end{array}$ & $\begin{array}{l}-0.5151 \\
(0.0607)\end{array}$ & $\begin{array}{l}-0.2086 \\
(0.0403)\end{array}$ \\
\hline$-\mathrm{R}^{2}$ & 0.68 & 0.73 & 0.49 & 0.64 & 0.67 & 0.43 \\
\hline \multicolumn{7}{|c|}{ UK } \\
\hline$-\beta$ & $\begin{array}{l}-0.5742 \\
(0.0822)\end{array}$ & $\begin{array}{l}-0.5991 \\
(0.0769)\end{array}$ & $\begin{array}{l}-0.3857 \\
(0.0993)\end{array}$ & $\begin{array}{l}-0.6246 \\
(0.0710)\end{array}$ & $\begin{array}{l}-0.6969 \\
(0.0691)\end{array}$ & $\begin{array}{l}-0.4587 \\
(0.0849)\end{array}$ \\
\hline$-\mathrm{R}^{2}$ & 0.60 & 0.65 & 0.32 & 0.70 & 0.76 & 0.47 \\
\hline \multicolumn{7}{|c|}{ US } \\
\hline$-\beta$ & $\begin{array}{l}-0.7128 \\
(0.0557)\end{array}$ & $\begin{array}{l}-0.7564 \\
(0.0495) \\
\end{array}$ & $\begin{array}{l}-0.5563 \\
(0.0703) \\
\end{array}$ & $\begin{array}{l}-0.7267 \\
(0.0453) \\
\end{array}$ & $\begin{array}{l}-0.7427 \\
(0.0468) \\
\end{array}$ & $\begin{array}{l}-0.6667 \\
(0.0502) \\
\end{array}$ \\
\hline$-\mathrm{R}^{2}$ & 0.82 & 0.87 & 0.64 & 0.88 & 0.87 & 0.83 \\
\hline
\end{tabular}


flows on the labor market proceed more between working and unemployed persons than female flows. Usually the $\beta$ coefficients for men significantly exceeded 0.5 , indicating that net flows proceeded mainly between working and unemployed persons. Coefficients for women were usually below 0.5 , indicating that net flows proceeded largely between working and inactive persons. The smallest disparities between men and women were declared for the US, while the greatest - for Australia and France. Repeatedly deviating results were obtained for the labor market in Japan, where the $\beta$ coefficients were very low, in particular in a version with the first differences, both for men and women.

The results presented in Table 2 concerned the entire period after 1980. However, in the past decades many countries have experienced significant changes, partially stimulated by actions striving for leveling out disparities in the male and female situation on the labor market. Therefore, it is justified to accept the hypothesis that relations between changes in a number of unemployed and working persons have altered, which may modify the above-presented conclusions. In the context of the hypothesis concerning liquidation of the gender gap, it is particularly important whether the above-stated differences between the $\beta$ coefficients for men and women have reduced. The moving regression analysis was conducted to answer those questions. Figure 1 presents the results for twenty-year moving regressions. They indicate large differences in change trends on particular national markets concerning both the direction of changes in $\beta$ and gender-specific ranges between coefficients. Depending on the adopted criterion, the analyzed countries may be divided into different groups.

The first criterion may be constituted by change in the range of $\beta$ coefficients for men and women. In this case, the subject of interest is whether differences in net flows on the labor market have changed. A significant decrease in those differences has occurred in four countries: Australia, Denmark, UK, and US. For models covering data after the year 1990 differences were insignificant, indicating a declining gender significance in net flows on the labor market. However, reasons for reduced differences were diverse. In Australia, there occurred a strong decrease in the $\beta$ coefficients for men, with its significantly more subtle change for women. Male flows on the labor market became similar to female flows. In Denmark and United Kingdom changes were opposite. Coefficients for women were more and more negative, indicating that female flows became similar to male flows. France and Japan constitute the second group of countries, where differences between men and women were maintained despite changes in $\beta$. In France, the value of coefficients decreased, indicating an increased significance of flows between working and inactive persons in a group of men and women. In Japan, coefficients were subject to short-term changes, however without a clearly specified trend. The third group of countries covered Canada and South Korea, where a large increase in the range between the $\beta$ coefficients for men and women was declared. In Canada, at a great stability of the coefficient for men, its value for women significantly decreased. Therefore, in reference to women, participation of flows between working and inactive persons increased. In Korea, both coefficients at the end of the analyzed period were more negative, but changes for men were significantly larger.

The second criterion for country grouping may be based on a direction of changes in the $\beta$ coefficient for women. In this case, the subject of interest is whether, in reference to women, participation of flows between working and unemployed persons is growing, while partici- 
pation of flows between working and inactive persons is falling. Such a trend was noticed in four countries: Denmark, South Korea, United Kingdom, and United States. However, in Canada and France changes were going in an opposite direction, while changes in Australia and Japan were subtle. In those two countries, though, coefficients were less negative after the 2008 financial crisis.

Australia

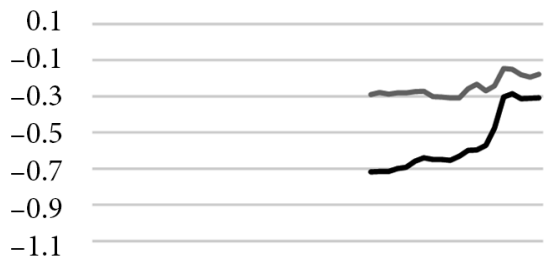

Denmark

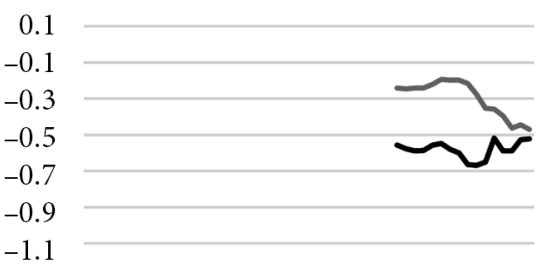

Japan

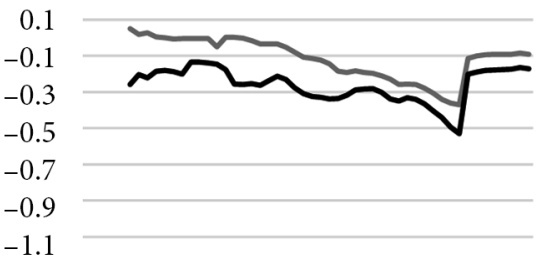

UK

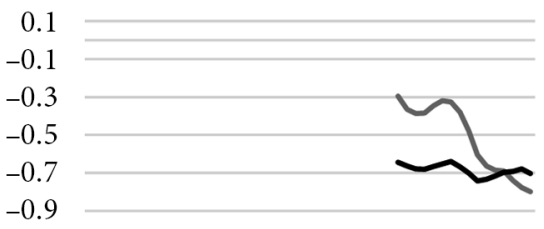

$-1.1$

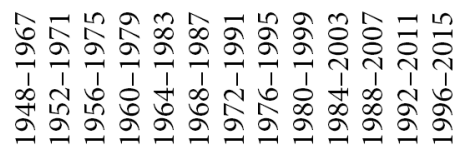

Canada

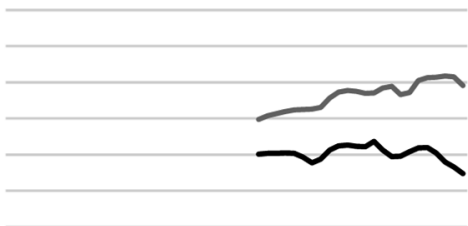

France

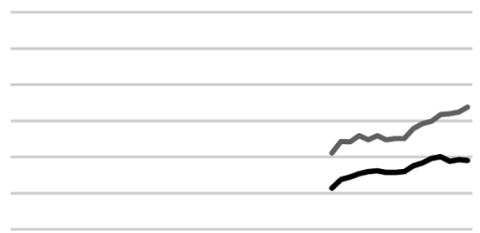

Rep. of Korea

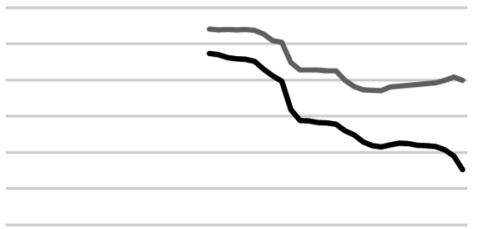

US

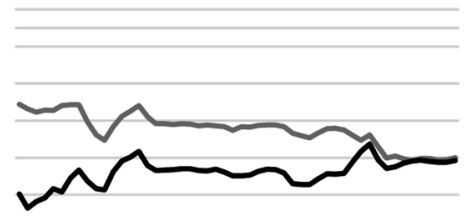

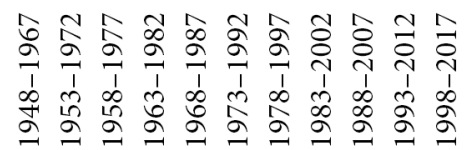

Female Male

Note: Australia (1998-2017), Canada (1995-2018), Denmark (2002-2017), France (2002-2017), Japan (1972-2018), Rep. of Korea (1989-2017), UK (2002-2017), US (1967-2018).

Figure 1. Coefficients of moving regression of a change in a number of unemployed against a change in a number of working persons (model 4 , deviations from the trend, moving regression for 20-year periods) (source: own calculations based on the ILO data) 
Theoretical prerequisites and empirical studies indicate that flows on the labor market are highly sensitive to a phase of the economic cycle. Therefore, in the conducted analyses one strived for defining whether the cycle phase differentiates the $\beta$ coefficient value and whether that effect was different for men and women. According to methodological comments, with

Table 3. Changes in a number of unemployed and changes in a number of working persons - results of the regression (model 4) in selected countries in the years 1981-2018 (source: own calculations based on the ILO data)

\begin{tabular}{|c|c|c|c|c|c|c|}
\hline \multirow{2}{*}{ Kraj } & \multicolumn{2}{|c|}{ Total } & \multicolumn{2}{|c|}{ Male } & \multicolumn{2}{|c|}{ Female } \\
\hline & $\mathrm{E}+$ & E- & $\mathrm{ME}+$ & ME- & $\mathrm{FE}+$ & FE- \\
\hline \multicolumn{7}{|c|}{ Australia } \\
\hline$-\beta_{+}, \beta_{-}$ & $\begin{array}{l}-0.4222 \\
(0.0969)\end{array}$ & $\begin{array}{l}-0.5406 \\
(0.1168)\end{array}$ & $\begin{array}{l}-0.5197 \\
(0.1015)\end{array}$ & $\begin{array}{l}-0.7544 \\
(0.1238)\end{array}$ & $\begin{array}{l}-0.3001 \\
(0.0833)\end{array}$ & $\begin{array}{l}-0.2378 \\
(0.0945)\end{array}$ \\
\hline$-\mathrm{R}^{2}$ & 0.66 & & 0.75 & & 0.49 & \\
\hline \multicolumn{7}{|c|}{ Canada } \\
\hline$-\beta_{+}, \beta_{-}$ & $\begin{array}{l}-0.5019 \\
(0.1015)\end{array}$ & $\begin{array}{l}-0.7727 \\
(0.1247)\end{array}$ & $\begin{array}{l}-0.5756 \\
(0.0840)\end{array}$ & $\begin{array}{l}-0.8730 \\
(0.0883)\end{array}$ & $\begin{array}{l}-0.4485 \\
(0.1122)\end{array}$ & $\begin{array}{c}-0.3972 \\
(0.1618)\end{array}$ \\
\hline$-\mathrm{R}^{2}$ & 0.78 & & 0.88 & & 0.55 & \\
\hline \multicolumn{7}{|c|}{ Denmark } \\
\hline$-\beta_{+}, \beta_{-}$ & $\begin{array}{l}-0.5336 \\
(0.1643)\end{array}$ & $\begin{array}{l}-0.3986 \\
(9.1584)\end{array}$ & $\begin{array}{l}-0.5442 \\
(0.1460)\end{array}$ & $\begin{array}{l}-0.5415 \\
(0.1311)\end{array}$ & $\begin{array}{l}-0.5859 \\
(0.1883)\end{array}$ & $\begin{array}{l}-0.0740 \\
(0.1618)\end{array}$ \\
\hline$-\mathrm{R}^{2}$ & 0.50 & & 0.63 & & 0.35 & \\
\hline \multicolumn{7}{|c|}{ France } \\
\hline$-\beta_{+}, \beta_{-}$ & $\begin{array}{l}-0.8552 \\
(0.1815)\end{array}$ & $\begin{array}{l}-0.6244 \\
(0.1707)\end{array}$ & $\begin{array}{l}-1.0550 \\
(0.1312)\end{array}$ & $\begin{array}{l}-0.5556 \\
(0.1246)\end{array}$ & $\begin{array}{l}-0.5138 \\
(0.1931)\end{array}$ & $\begin{array}{l}-0.4829 \\
(0.2171)\end{array}$ \\
\hline$-\mathrm{R}^{2}$ & 0.66 & & 0.84 & & 0.39 & \\
\hline \multicolumn{7}{|c|}{ Japan } \\
\hline$-\beta_{+}, \beta_{-}$ & $\begin{array}{l}-0.4383 \\
(0.0851)\end{array}$ & $\begin{array}{l}-0.0251 \\
(0.0581)\end{array}$ & $\begin{array}{l}-0.5036 \\
(0.0988)\end{array}$ & $\begin{array}{l}-0.0433 \\
(0.0664)\end{array}$ & $\begin{array}{l}-0.2828 \\
(0.0678)\end{array}$ & $\begin{array}{l}-0.0141 \\
(0.0514)\end{array}$ \\
\hline$-\mathrm{R}^{2}$ & 0.47 & & 0.47 & & 0.36 & \\
\hline \multicolumn{7}{|c|}{ Rep. of Korea } \\
\hline$-\beta_{+}, \beta_{-}$ & $\begin{array}{l}-0.2919 \\
(0.1131)\end{array}$ & $\begin{array}{l}-0.4557 \\
(0.0772)\end{array}$ & $\begin{array}{l}-0.3077 \\
(0.1195)\end{array}$ & $\begin{array}{l}-0.6616 \\
(0.0939)\end{array}$ & $\begin{array}{l}-0.1401 \\
(0.1026)\end{array}$ & $\begin{array}{l}-0.2452 \\
(0.0646)\end{array}$ \\
\hline$-\mathrm{R}^{2}$ & 0.65 & & 0.71 & & 0.44 & \\
\hline \multicolumn{7}{|c|}{ UK } \\
\hline$-\beta_{+}, \beta_{-}$ & $\begin{array}{l}-0.4049 \\
(0.1105)\end{array}$ & $\begin{array}{l}-0.9716 \\
(0.1547)\end{array}$ & $\begin{array}{l}-0.4800 \\
(0.1150)\end{array}$ & $\begin{array}{l}-1.0015 \\
(0.1482)\end{array}$ & $\begin{array}{l}-0.2923 \\
(0.1354)\end{array}$ & $\begin{array}{l}-0.7311 \\
(0.1938)\end{array}$ \\
\hline$-\mathrm{R}^{2}$ & 0.75 & & 0.79 & & 0.51 & \\
\hline \multicolumn{7}{|c|}{ US } \\
\hline$-\beta_{+}, \beta_{-}$ & $\begin{array}{l}-0.4592 \\
(0.0753)\end{array}$ & $\begin{array}{l}-0.9828 \\
(0.0729)\end{array}$ & $\begin{array}{l}-0.4306 \\
(0.0694)\end{array}$ & $\begin{array}{l}-1.0293 \\
(0.0653)\end{array}$ & $\begin{array}{l}-0.5265 \\
(0.0992)\end{array}$ & $\begin{array}{l}-0.8038 \\
(0.0976)\end{array}$ \\
\hline$-\mathrm{R}^{2}$ & 0.92 & & 0.93 & & 0.84 & \\
\hline
\end{tabular}

Note: standard deviations in brackets. 


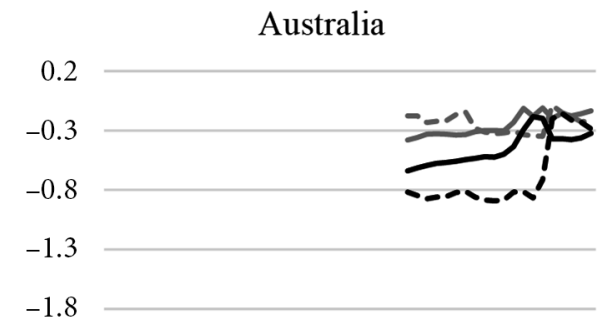

Denmark

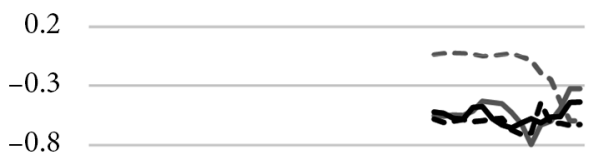

$-1.3$

$-1.8$

Japan

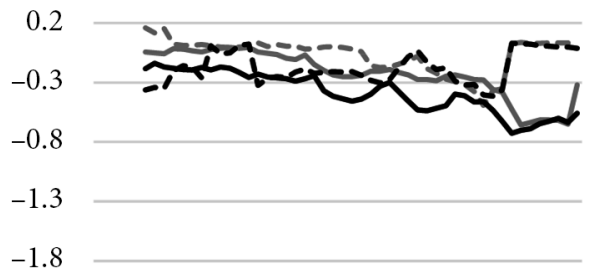

UK

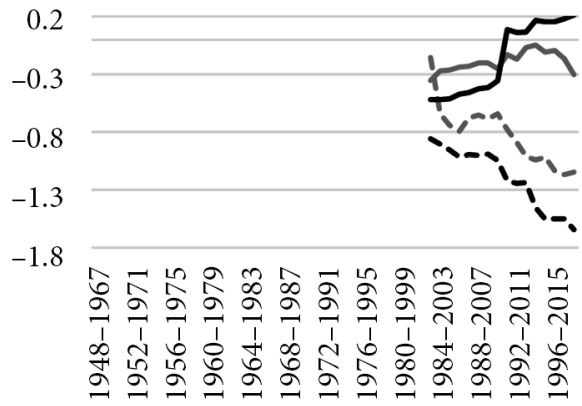

Canada

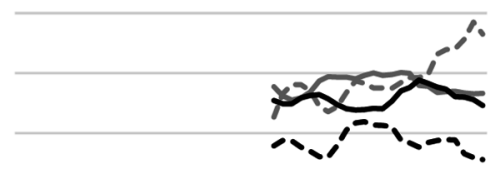

France

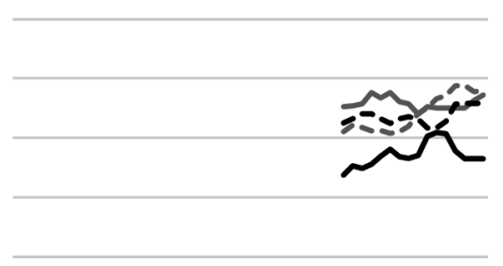

Rep. of Korea

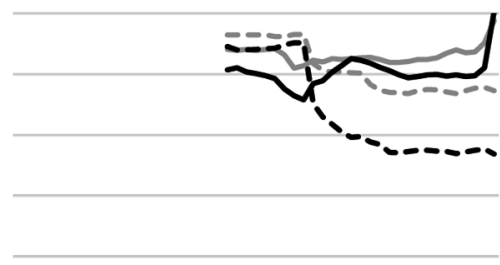

US

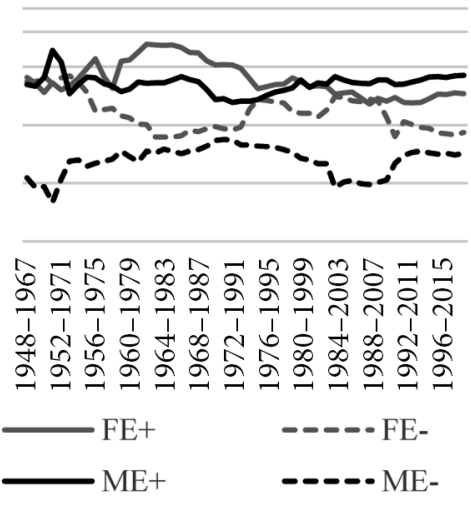

Note: Australia (1998-2017), Canada (1995-2018), Denmark (2002-2017), France (2002-2017), Japan (1972-2018), Rep. of Korea (1989-2017), UK (2002-2017), US (1967-2018).

Figure 2. Coefficients of moving regression for 20-year periods - models for deviations from the trend (change in a number of working persons towards changes in a number of the unemployed for increases and decreases in a number of working persons) in selected countries (source: own calculations based on the ILO data) 
use of the model (5), coefficients were calculated separately for positive and negative cyclical deviations of a number of working persons. Results for the entire period after 1980 were presented in Table 3, while Figure 2 presents results for 20-year moving regressions. Those results were highly diverse. It is impossible to draw from them common conclusions for all countries, which indicates a major significance of specific national conditions for labor markets. However, general diversity of results between particular countries decreased for periods of a cyclical increase in employment. In the prosperity periods, at least half of inflows to working persons came from inactive persons. Only France was an exception. Greater diversity between countries was stated for the recession periods. In United Kingdom and United States, a decrease in a number of working persons was equal to an increase in a number of the unemployed, thus all net flows in the recession period concerned the outflow from working to unemployed persons. The labor market in Japan was the opposite. In the recession period, a decrease in employment was not associated with an increase in unemployment, thus practically all net employment outflows were related to the flow from working to inactive persons.

Differentiation of the $\beta$ coefficients between men and women was not significantly changed, when the economic cycle period was considered. The coefficients were more negative for a group of men both for the periods of prosperity and recession. In the recession periods, women flow from working to inactive persons more often, while in the periods of better economic situation the employment inflow of women from a group of inactive persons is more intense. Some specificity may be stated for labor markets in Denmark and Japan. In Denmark, differences between men and women concerned only the recession periods. For those periods, almost all net employment outflows of women were connected with the inactivity inflow. In the case of men, only half of them outflowed to inactivity, while the other half - to unemployment. In turn, in Japan, both men and women outflowed from employment to inactivity in the recession periods. Differences concerned periods of increased employment, when relatively more men inflowed from unemployment to employment.

As previous analyses showed changes in the estimated $\beta$ coefficients and diversity depending on the cycle phase, those aspects were combined in one analysis. Figure 2 presents the results. Previously there was stated a significant decrease in differences between men and women in Australia, Denmark, United Kingdom, and United States. The analysis considering the cycle phase indicates that differences occurring in those countries in the past concerned mainly the recession periods, when employment was falling against the trend. In the past, in the recession periods women transferred to inactivity much more often than men. In Australia, Denmark and United States, that difference almost disappeared during the analyzed period and connections between changes in unemployment and employment were similar for men and women regardless of the cycle phase. In addition, in Australia and Denmark differences between the cycle phases decreased. In the United States those differences for men were maintained, while for women the cycle phase at the end of the analyzed period did not differentiate the connection of changes in unemployment and employment. Specificity of the cycle phase was more visible on the British labor market. In UK, in the earlier analyses there was stated a decrease in average differences between the $\beta$ coefficients calculated for men and women. However, another analysis showed that although those coefficients, particularly for periods of negative deviations of employment, changed in the same direction, differences 
between results for positive and negative deviations of male employment were deepened. As a consequence, significance of the cycle phase on the labor market in United Kingdom increased, especially for men. Therefore, it is hard to talk about a complete decline of differences in male and female flows on the British labor market.

In Japan, differences between the $\beta$ coefficients for the periods of increase and decrease in employment were not gender-specific. They became more negative for the periods of decrease in unemployment, although that change was partially ironed out for the period after 2009. In turn, the previous analysis showed maintenance of differences between the $\beta$ coefficients for men and women. As data on Figure 2 show, these differences concern the periods of an increase in employment, where decrease in female unemployment is significantly lower than for men.

The previous analysis indicated that in Canada and South Korea differences between the $\beta$ coefficients for men and women increased. That increase resulted from deepened differences for the recession periods. In Canada, coefficients for women were subject to a significant decrease, indicating that in the recession period women transferred to inactivity more and more often. No such dependency was stated for men. In turn, in South Korea, in the recession periods men transferred to unemployment to a greater extent. That increase occurred also for women, but was significantly smaller.

\section{Conclusions}

Segmentation on the labor market may be of diverse nature and reasons. Distinct, genderrelated treatment of employees on the labor market constitutes one of its indications. Analyses conducted for eight countries indicate that the employment of women and their share in a number of working persons have increased in all countries. While the rate of unemployment for men and women is similar, that may indicate the reduction of the (phenomenon of) discrimination of women on the labor market, however this issue is more complicated.

That is why the paper offers an alternative methodological approach to the analysis and assessment of the women's situation on the labor market. The analysis was based on the regression of changes in a number of unemployed against a number of working persons.

While following that approach, it was stated that in all analyzed countries relations between changes in a number of unemployed against a number of working persons were poorer in reference to women. This conclusion confirms the hypothesis that women are more secondary workers on the labor market. However, the results were differentiated according to the country and were subject to changes over time. In Denmark, largely in Australia, United Kingdom and United States, differences in flows of men and women clearly decreased or disappeared, in particular after 2000. However, in Canada and South Korea, differences between genders increased. In France and Japan, they stayed at a similar level. Therefore, the hypothesis concerning the reduction or liquidation of differences between men and women in a relation of changes in a number of unemployed and working persons was confirmed only partially, in reference to the selected labor markets. In addition, the economic cycle phase constituted a factor differentiating male and female flows. In the recession periods women flowed (transferred) to a group of inactive persons more than men. This conclusion verifies 
positively the hypothesis that in recession women are seen as secondary workers more often than men.

Gender-related discrimination on the labor market is more country-specific than universal. In this context, it would be interesting to compare it with results for markets of developing countries, where the women's situation seems to be more difficult, with different historically formed social roles of women and different institutional conditions. An interesting direction of further analyses would be constituted by the consideration of stereotypes and a level of use of flexible employment forms among women in the explanation of their secondary role on the labour market. The conducted analyses indicate huge differences in time. While women have largely caught men up with regard to education and reduced the gap in professional experience, trends in flows between employed and unemployed and nonactive persons continue. The conducted research aimed at an attempt at the involvement in a discussion on women's discrimination on the labour market, focusing on the factors less examined so far. Identification of factors triggering differences between countries and changes over time of the relation a number of unemployed and of working persons would enable not only to better understand the (phenomenon of) discrimination on the labor market, but also to indicate tools that reduce it.

\section{Author contributions}

Jerzy Rembeza, Kamila Radlińska conceived the study. J. Rembeza, K. Radlińska were responsible for the design and development of the data analysis. J. Rembeza, K. Radlińska were responsible for data collection and analysis. J. Rembeza, K. Radlińska were responsible for data interpretation. J. Rembeza wrote the first draft of the article.

\section{References}

Acemoglu, D., \& Autor, D. (2011). Skills, tasks and technologies: Implications for employment and earnings. In Handbook of labor economics (Vol. 4, pp. 1043-1171). Elsevier.

https://doi.org/10.1016/S0169-7218(11)02410-5

Agarwal, B. (1997). Bargaining and gender relations: Within and beyond the household. Feminist Economics, 3(1), 1-51. https://doi.org/10.1080/135457097338799

Albanesi, S., \& Sahin, A. (2018). The gender unemployment gap. Review of Economic Dynamics, 30, 47-67. https://doi.org/10.1016/j.red.2017.12.005

Amable, B., Demmou, L., \& Gatti, D. (2006). Institutions, unemployment and inactivity in the OECD countries (Working paper No. 16). Paris-Jourdan Sciences Économiques.

Azmat, G., Güell, M., \& Manning, A. (2006). Gender gaps in unemployment rates in OECD countries. Journal of Labor Economics, 24(1), 1-37. https://doi.org/10.1086/497817

Bachmann, R., \& Sinning, M. (2016). Decomposing the ins and outs of cyclical unemployment. Oxford Bulletin of Economics and Statistics, 78(6), 853-876. https://doi.org/10.1111/obes.12133

Bentolila, S., Dolado, J. J., \& Jimeno, J. F. (2019). Dual labour markets revisited (CESifo Working Paper No. 7479). https://ssrn.com/abstract=3338834

Bertrand, M., \& Hallock, K. F. (2001). The gender gap in top corporate jobs. ILR Review, 55(1), 3-21. https://doi.org/10.1177/001979390105500101 
Blanchard, O. J. (2006). European unemployment: The evolution of facts and ideas. Economic Policy, 21(45), 6-59. https://doi.org/10.1111/j.1468-0327.2006.00153.x

Blanchard, O. J., Diamond, P., Hall, R. E., \& Murphy, K. (1990). The cyclical behavior of the gross flows of US workers. Brookings Papers on Economic Activity, 1990(2), 85-155. https://doi.org/10.2307/2534505

Borland, J., \& Coelli, M. (2016). Labour market inequality in Australia. Economic Record, 92(299), 517-547. https://doi.org/10.1111/1475-4932.12285

Boston, T. D. (1990). Segmented labor markets: New evidence from a study of four race-gender groups. ILR Review, 44(1), 99-115. https://doi.org/10.1177/001979399004400107

Buddelmeyer, H., Wang-Sheng L., \& Wooden, M. (2010). Low-paid employment and unemployment dynamics in Australia. Economic Record, 86(272), 28-48. https://doi.org/10.1111/j.1475-4932.2009.00595.x

Cappellari, L. (2007). Earnings mobility among Italian low-paid workers. Journal of Population Economics, 20(2), 465-482. https://doi.org/10.1007/s00148-006-0065-z

Dickens, W., \& Lang, K. (1985). Testing dual labor market theory: A reconsideration of the evidence (Working Paper No. 1670). National Bureau of Economic Research. https://doi.org/10.3386/w1670

Eichhorst, W., Marx, P., \& Wehner, C. (2017). Labor market reforms in Europe: Towards more flexicure labor markets? Journal for Labour Market Research, 51(1), 3. https://doi.org/10.1186/s12651-017-0231-7

Elsby, M. W. L., Michaels, G., \& Solon, G. (2009). The ins and outs of cyclical unemployment. American Economic Journal: Macroeconomics, 1(1), 84-110. https://doi.org/10.1257/mac.1.1.84

Fernández-Macías, E., \& Vacas, C. (2015). Recent developments in the distribution of wages in Europe. Publications Office of the European Union.

Fortin, N. M. (2005). Gender role attitudes and the labour-market outcomes of women across OECD countries. Oxford Review of Economic Policy, 21(3), 416-438. https://doi.org/10.1093/oxrep/gri024

Gimenez-Nadal, I., \& Molina, J. A. (2014). Regional unemployment, gender, and time allocation of the unemployed. Review of Economics of the Household, 12(1), 105-127. https://doi.org/10.1007/s11150-013-9186-9

Graham, J., \& Shakow, D. M. (1990). Labor market segmentation and job-related risk: Differences in risk and compensation between primary and secondary labor markets. American Journal of Economics and Sociology, 49(3), 307-323. https://doi.org/10.1111/j.1536-7150.1990.tb02285.x

Hall, R. E., Gordon, A., \& Holt, Ch. (1972). Turnover in the labor force. Brookings Papers on Economic Activity, 1972(3), 709-764. https://www.jstor.org/stable/2534130

Heywood, J. S., Siebert, W. S., \& Wei, X. (2007). The implicit wage costs of family friendly work practices. Oxford Economic Papers, 59(2), 275-300. https://doi.org/10.1093/oep/gpm006

Hudson, K. (2007). The new labor market segmentation: Labor market dualism in the new economy. Social Science Research, 36(1), 286-312. https://doi.org/10.1016/j.ssresearch.2005.11.005

Jung, H., \& Cho, J. (2020). Gender inequality of job security: veiling glass ceiling in Korea. Journal of the Asia Pacific Economy, 25(1), 79-98. https://doi.org/10.1080/13547860.2019.1631528

Kim, J., Lee, J-W., \& Shin, K. (2018). Gender inequality and economic growth in Korea. Pacific Economic Review, 23(4), 658-682. https://doi.org/10.1111/1468-0106.12181

Lažetić, P. (2020). The gender gap in graduate job quality in Europe - a comparative analysis across economic sectors and countries. Oxford Review of Education, 46(1), 129-151. https://doi.org/10.1080/03054985.2019.1687439

McDonald, I. M., \& Solow, M. R. (1985). Wages and employment in a segmented labor market. The Quarterly Journal of Economics, 100(4), 1115-1141. https://doi.org/10.2307/1885677 
Mosthaf, A., Schank, T., \& Schnabel, C. (2014). Low-wage employment versus unemployment: Which one provides better prospects for women? IZA Journal of European Labor Studies, 3(1), 21. https://doi.org/10.1186/2193-9012-3-21

Mukhopadhyay, M. (2016). Mainstreaming gender or "streaming" gender away: Feminists marooned in the development business. In The Palgrave handbook of gender and development (pp. 77-91). Palgrave Macmillan. https://doi.org/10.1007/978-1-137-38273-3_6

Nickell, S., Nunziata, L., \& Ochel, W. (2004). Unemployment in the OECD since the 1960s. What do we know? The Economic Journal, 115(500), 1-27. https://doi.org/10.1111/j.1468-0297.2004.00958.x

Ogawa, S. (2019). Dynamic analysis of a disequilibrium macroeconomic model with dual labor markets. Metroeconomica, 70(3), 525-550. https://doi.org/10.1111/meca.12255

Osterman, P. (1985). An empirical study of labor market segmentation. ILR Review, 28(4), 508-523. https://doi.org/10.1177/001979397502800402

Pascall, G. (2008). Gender and European Welfare States. In C. Aspalter \& P. Abrahamson (Eds.), Understanding European Social Policy. Casa Verde Publishing.

Petrongolo, B., \& Pissarides, C. A. (2001). Looking into the black box: A survey of the matching function. Journal of Economic Literature, 39(2), 390-431. https://doi.org/10.1257/jel.39.2.390

Powell, L. M. (1997). The impact of child care costs on the labour supply of married mothers: Evidence from Canada. Canadian Journal of Economics, 30(3), 577-594. https://www.jstor.org/stable/136234

Ridgeway, C. L. (1997). Interaction and the conservation of gender inequality: Considering employment. American Sociological Review, 62(2), 218-235. https://www.jstor.org/stable/2657301

Saint-Paul, G. (1996). Dual labor markets: a macroeconomic perspective. MIT Press.

Sánchez-Mira, N. (2019). Work-family arrangements and the crisis in Spain: Balkanized gender contracts? Gender, Work \& Organization, 1-27. https://doi.org/10.1111/gwao.12417

Seguino, S. (2000). Accounting for gender in Asian economic growth. Feminist Economics, 6(3), 27-58. https://doi.org/10.1080/135457000750020128

Shimer, R. (2012). Reassessing the ins and outs of unemployment. Review of Economic Dynamics, 15(2), 127-148. https://doi.org/10.1016/j.red.2012.02.001

Siebert, H. (1997). Labor market rigidities: At the root of unemployment in Europe. Journal of Economic Perspectives, 11(3), 37-54. https://doi.org/10.1257/jep.11.3.37

Stephan, G. (2010). Employer wage subsidies and wages in Germany: Empirical evidence from individual data. Zeitschrift für Arbeitsmarkt Forschung, 43(1), 53-71. https://doi.org/10.1007/s12651-010-0029-3

Svarer, M. (2011). The effect of sanctions on exit from unemployment: Evidence from Denmark. Economica, 78(312), 751-778. https://doi.org/10.1111/j.1468-0335.2010.00851.x

Van den Berg, G. J., \& Vikström, J. (2014). Monitoring job offer decisions, punishments, exit to work, and job quality. The Scandinavian Journal of Economics, 116(2), 284-334. https://doi.org/10.1111/sjoe.12051

Wachter, M. L. (1972). A labor supply model for secondary workers. The Review of Economics and Statistics, 54(2), 141-151. https://www.jstor.org/stable/1926274 


\section{APPENDIX}

Australia

16

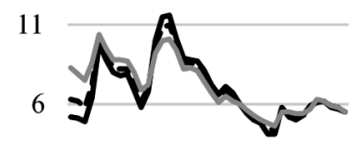

1

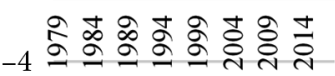

France

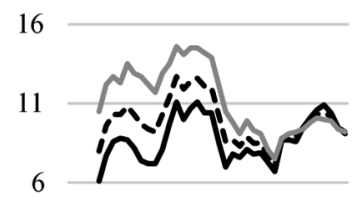

1

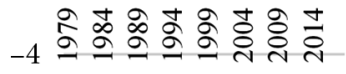

UK

16

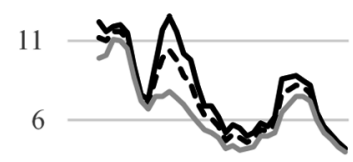

1

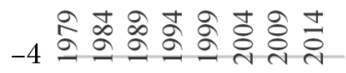

Canada

16

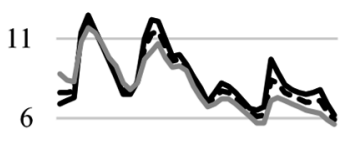

1

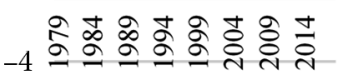

Japan

16

11

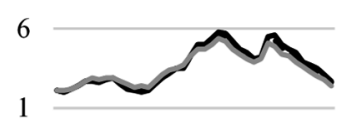

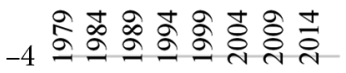

US

16

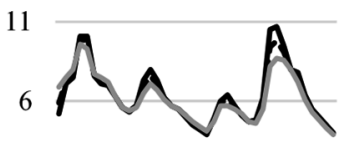

1

尺े
Denmark

16

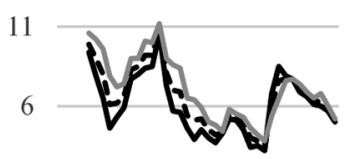

1

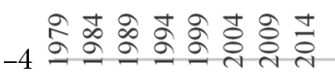

Rep. of Korea

16

11

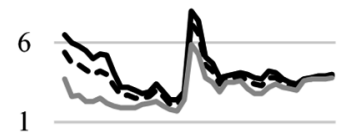

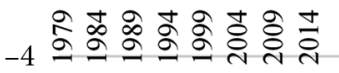

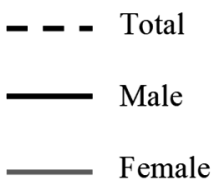

Note: Australia (1979-2017), Canada (1979-2018), Denmark (1983-2017), France (1983-2017), Japan (1979-2018), Rep. of Korea (1980-2017), UK (1983-2017), US (1979-2018).

Figure 3. Unemployment rates of male and female (source: own calculations based on the ILO data) 


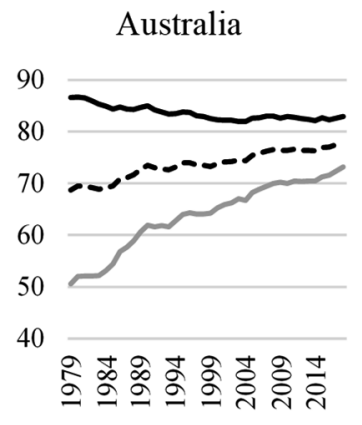

France

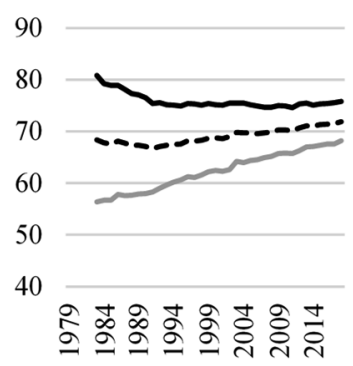

UK

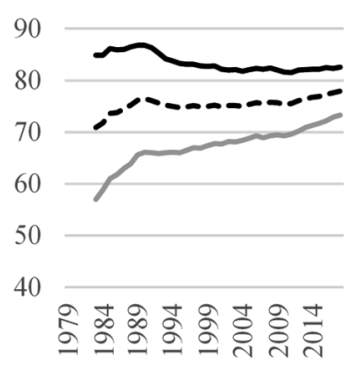

Canada

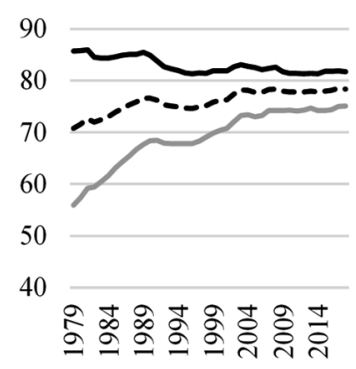

Japan

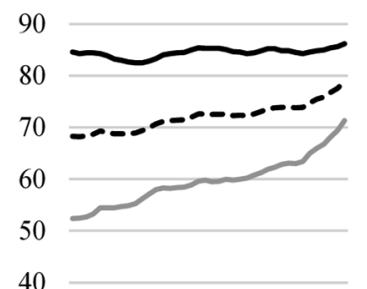

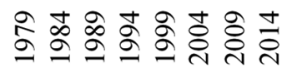

Denmark

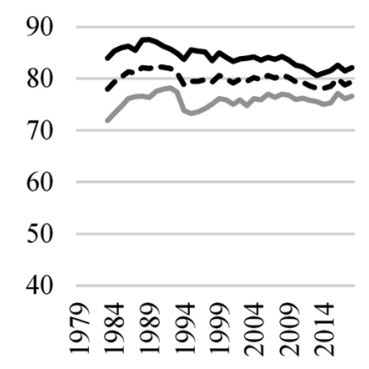

Rep. of Korea

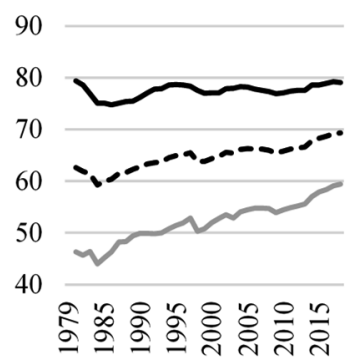

Note: Australia (1979-2017), Canada (1979-2018), Denmark (1983-2017), France (1983-2017), Japan (1979-2018), Rep. of Korea (1980-2017), UK (1983-2017), US (1979-2018).

Figure 4. Participation rates of male and female (source: own calculations based on the ILO data) 